\title{
POLA KOMUNIKASI ANTAR ANGGOTA KOMUNITAS ANAK PUNK DI KOTA CURUP KABUPATEN REJANG LEBONG
}

\author{
Oleh : \\ HENDI SEPTIADI, VETHY OCTAVIANI, ANTONIO IMANDA \\ Prodi Ilmu Komunikasi FIS Universitas Dehasen Bengkulu
}

\begin{abstract}
This study aimed to determine the communication patterns between punk community member in Curup Rejang Lebong. This study used qualitative research methods, with descriptive research approach. Informants in this study were four members of the punk community. Data collection techniques used by researchers were observation, interviews and documentation. The results showed that the patterns of communication used by members of punk were: one-way communication pattern, two-way communication pattern, and multidirectional communication pattern. In the pattern of one-way communication, punk community members act as listeners or communication made in the form of instructions through mobile media (handphone). This two-way communication patterns better clarify the pattern of one-way communication where the causal direction alternates for their feedback whether the message could be understood and accepted. Multidirectional communication patterns occur in this community go well, because here they exchange ideas or discuss and receive advice among fellow community through consultation conducted every month to pull out the ideas that could be useful for the progress of the punk community members and strengthen the relationships between community members.
\end{abstract}

Keywords: Punk, Community, Communication Patterns, Curup

\section{PENDAHULUAN}

Masa remaja adalah masa dimana seorang anak belum mendapatkan pegangan yang kuat secara rohani dan jasmani, sedangkan kepribadiannya sedang mengalami pembentukan. Keluarga merupakan lingkungan sosial pertama yang memberikan kontribusi dalam pembentukan kepribadian yang sangat besar bagi tumbuh kembangnya anak sehingga remaja dapat mencapai tingkat kedewasaan, dengan kata lain bahwa anakanak akan ideal perkembangan jasmani dan rohaninya apabila mereka tumbuh bersama keluarga mereka yang harmonis.

Pada kenyataannya tidak semua keluarga dapat memenuhi kebutuhan ideal. Perubahan sosial, ekonomi dan budaya sangat berpengaruh terhadap keberlangsungan keluarga, keharmonisan keluarga kadang terusik oleh perubahan sosial, ekonomi, dan budaya yang tumbuh dan berkembang di masyarakat dan terkadang dapat menghepaskan keluarga kedalam jurang kemiskinan.

Perubahan tersebut berdampak pada gaya hidup masyarakat terutama pada gaya hidup anarkis yang membuat mereka merasa mendapat kebebasan. Sekelompok anak muda bergaya hidup punk dikarenakan adanya suatu gejala perasaan yang tidak puas, sehingga mereka dengan gaya hidup punk. Kaum punk memaknai anarkisme tidak hanya sebatas pengertian politik semata. Dalam keseharian hidup, anarkisme berarti tanpa aturan pengekangan dari masyarakat, karena mereka bisa menciptakan sendiri aturan hidup sesuai dengan keinginanya.

Punk merupakan sub-budaya yang lahir di London, Inggris, yang menjadi wadah untuk mencurahkan kritik dan 
protes atas penguasa pada waktu itu. Punk memiliki ideologi sosialis yang bersifat bebas. Punk lebih dikenal melalui gaya busananya seperti potongan rambut Mohawk (Jenis Rambut), jaket penuh dengan spike dan bedge, sepatu boots, jeans ketat, badan bertato, dan hidup di jalan-jalan. Proses modernisasi di Indonesia menyebabkan kehadiran Punk sebagai gaya hidup baru, yang umumnya dianut oleh sebagian kaum muda. Punk kemudian lebih dikenal sebagai tata cara hidup sehari-hari, dengan ekspresi diri yang menjurus pada gaya hidup bebas seperti: free sex, nongkrong di jalan, ngamen, mengkonsumsi alkohol, main musik dengan pogo, dan gaya busana yang nyeleneh. Orang-orang yang mengikuti gaya hidup Punk disebut anak Punk. (http://id.wikipedia.org/wiki/Punk di akses tanggal 3 april 2016).

Persebaran gaya hidup Punk sangat marak di kota-kota di Indonesia, salah satunya di Kota Curup Kabupaten Rejang Lebong. Anak Punk yang ingin hidup bebas, tanpa ada aturan yang mengatur segala aktivitas serta perilaku mereka, menjadi sebuah masalah yang perlu dikaji dalam penelitian ini. Berbeda hal dengan anak punk yang berada di Curup tepatnya di Jl. MH Tamrin Air Rambai yang biasa menjadi tempat mereka mencari uang (ngamen) sedangkan tempat mereka berkumpul di Jl. Merdeka (basecamp).

Berdasarkan hasil prapenelitian terhadap komunitas anak punk yang di lakukan pada hari Rabu tanggal 30 Maret 2016 di J1. Merdeka Kota Curup, anak punk tersebut tidak memiliki ketua ataupun pemimpin mereka hanya komunitas yang dibentuk berdasarkan kesamaan, rata-rata anak punk dengan jumlah kurang lebih 30 orang tidak memiliki pendidikan yang memadai, hal ini dikarenakan pergaulan dan adanya broken home di keluarga mereka. Komunikasi yang digunakan atau bahasa sehari-hari adalah bahasa Indonesia dan ada beberapa yang menggunakan bahasa punk sebagai contoh Ngolek (ngamen), Melacak (bongkar barang),
Ngompreng (makanan sisa yang dibagikan). Anak punk yang berada di kota curup tidak berasal dari kota itu sendiri melainkan berbagai macam daerah seperti Medan, Bengkulu, Linggau. Hal-hal yang dikerjakan oleh anak punk selain ngamenya itu menjaga café jika diperlukan oleh pemilik cafe.

Komunitas punk yang berada di kota Curup hanya satu komunitas dengan jumlah 30 dari 25 laki-laki dan 5 perempuan. Di Curup punk sering berada di persimpangan lampu merah mereka juga mencari nafkah dipinggir jalan bukan hanya sekedar ngumpul-ngumpul saja tetapi mereka mengamen untuk mendapatkan uang. Sehingga membuat masyarakat resah dan takut dengan adanya keberadaan anak punk dikarenakan bau dari anak punk yang tidak mandi dan penampilan yang kurang baik.

Penampilan anak punk yang identik dengan pakaian berwarna hitam dan terkesan dekil membuat masyarakat melihat mereka seperti brandalan yang tidak memiliki aturan berkumpul di persimpangan jalan dan melakukan aktivitas seperti layaknya anak jalanan seperti mengamen bagi sebagian orang merupakan sesuatu yang merusak pandangan. Bahkan tak jarang aparat melakukan penangkapan terhadap anak punk kerena perilaku ugal-ugalan mereka. Padahal dibalik sepengetahuan sebagian orang, anak punk tak hanya merupakan kelompok yang bebas dan tidak memiliki aturan.

Para punk tepatnya di Jl. MH Tamrin Air Rambai dan Jl. Merdeka sering melakukan kegiatan-kegiatan rutin dan terencana yang bersifat positif seperti diskusi yang mana pada saat diskusi tersebut mereka akan membicarakan perkembangan setiap scene (kelompok kecil bagian dari komunitas punk dalam satu kota), menanam pohon dan bergotong royong membersihkan sampah disekitaran tempat mereka berkumpul di daerah tepatnya di Jl. MH Tamrin Air Rambai dan Jl. Merdeka dan sekitarnya, membuat 
acara musik punk yang terselenggara tanpa menggunakan sponsor atau bantuan dari pihak manapun di luar mereka, mereka juga menjual barang-barang seperti bajubaju hasil dari sablonan mereka dan atribut punk lainnya yang dijual di sebuah toko kecil yang disebut dengan distro yang menjadi tren remaja sekarang. Berdasarkan latar belakang tersebut, penulis tertarik untuk mengkaji bagaimana pola komunikasi antar anggota komunitas anak punk di kota Curup Kabupaten Rejang Lebong?

\section{METODE PENELITIAN}

Metode penelitian adalah serangkaian hukum, aturan, dan tata cara tertentu yang di atur dan ditentukan berdasarkan kaidah ilmiah dalam menyelenggarakan suatu penelitian dalam koridorke-ilmuwan tertentu yang hasilnya dapat dipertanggungjawabkan secara ilmiah. Penelitian tentang pola kumunikasi antar anggota komunitas anak punk di Kota Curup Kabupaten Rejang Lebong. Penelitian ini menggunakan metode penelitian kualitatif, yang pendekatannya memakai pendekatan deskriptif. Penelitian kualitatif adalah suatu penelitian ilmiah yang bertujuan untuk memahami suatu fenomena dalam konteks sosial secara alamiah dengan mengedepankan proses interaksi komunikasi yang mendalam antara peneliti dengan fenomena yang diteliti (Herdiansyah, 2010: 105).

Dalam penelitian ini penulis memilih Key Informan dan Informan yang sesuai dengan tujuan penulis atau yang dianggap memiliki informasi yang relevan dengan masalah pokok penelitian, antara lain: key informan dalam penelitian ini adalah orang yang dituakan didalam komunitas, dan informan pada penelitian ini adalah anak punk yang memiliki informasi yang relevan dengan masalah penelitian. Dalam penelitian ini yang menjadi informan adalah anggota komunitas yang ditunjukkan pada table berikut ini:
Tabel 1 Informan Kunci dan Informan Pokok

\begin{tabular}{|c|c|c|l|}
\hline No & Nama & Umur & Keterangan \\
\hline 1 & Pareng & 19 & Informan Kunci \\
\hline 2 & Agung & 18 & Informan Pokok \\
\hline 3 & Funky & 18 & Informan Pokok \\
\hline 4 & Rico & 18 & Informan Pokok \\
\multicolumn{4}{|c}{ Teknik pengumpulan data }
\end{tabular}

merupakan langkah yang paling strategis dalam penelitian, karena tujuan utama dari penelitian adalah untuk mendapatkan data. Dalam melakukan penelitian ini, peneliti menggunakan teknik pengumpulan data yaitu observasi, wawancara dan dokumentasi.

Analisis data adalah proses mencari dan menyusun secara sistematis data yang diperoleh melalui wawancara, catatan lapangan, dan bahan-bahan lain, sehingga dapat mudah dipahami, dan temuannya dapat di informasikan kepada orang lain. Dilakukan dengan mengorganisasikan data, menjabarkannya kedalam unit-unit, melakukan sintesa, menyusun kedalam pola, memilih dan membuat kesimpulan. Analisis data merupakan tahap yang menentukan dalam penelitian kualitatif yang terdiri dari tiga tahap, yaitu: Reduksi Data (Reduction) merupakan proses pemilihan, pemusatan perhatian, penyederhanaan, pengabtsrakan dan trans paransi data kasar yang muncul dari catatan lapangan. Oleh karena itu langkahlangkah yang di lakukan oleh peneliti adalah melakukan perampingan data dengan cara memilih data yang penting kemudian menyederhanakan dan mengabstraksikan. Dalam reduksi data ini, peneliti melakukan proses living in (data yang terpilih) dan living out (data yang terbuang) baik dari hasil pengamatan, wawancara maupun dokumentasi. Proses reduksi data ini tidak dilakukan pada akhir penelitian saja, tetapi dilakukan secara terus-menerus sejak proses pengumpulan data berlangsung karena reduksi data ini bukanlah suatu kegiatan yang terpisah dan berdiri sendiri dari proses analisis data, akan tetapi merupakan bagian dari proses 
analisis itu sendiri. Penyajian Data (display data) merupakan suatu proses pengorganisasian data sehingga mudah dianalisis dan disimpulkan. Penyajian data dalam penelitian ini berbentuk uraian narasi serta dapat diselingi dengan gambar, skema, matriks, tabel, rumus, dan lain-lain. Hal ini di sesuaikan dengan jenis data yang terkumpuldalam proses pengumpulan data, baik dari hasil observasi, wawancara, maupun studi dokumentasi. Penyajian data ini merupakan hasil reduksi data yang telah dilakukan sebelumnya agar menjadi sistematis dan bias diambil maknanya, karena bisaanya data yang terkumpul tidak sistematis. Verifikasi dan Kesimpulan Data merupakan langkah ketiga dalam proses analisis. Kesimpulan yang pada awalnya masih sangat tentatif, kabur, dan diragukan, maka dengan bertambahnya data, menjadi lebih grounded. Kegiatan ini merupakan proses memeriksa dan menguji kebenaran data yang telah dikumpulkan sehingga kesimpulan akhir di dapat sesuai dengan focus penelitian. Kesimpulan ini merupakan proses yang dilakukan selama penelitian dengan cara mencocok kan data dengan catatan-catatan yang telah dibuat peneliti dalam melakukan penarikan kesimpulan-kesimpulan awal. Karena pada dasarnya penarikan kesimpulan sementara dilakukan sejak awal pengumpulan data. Data yang telah di verifikasi, akan dijadikan landasan dalam melakukan penarikan kesimpulan. Kesimpulan awal yang telah dirumuskan dicek kembali (verifikasi) pada catatan yang telah di buat oleh peneliti dan selanjutnya menuju ke arah kesimpulan yang mantap. Kesimpulan merupakan intisari dari hasil penelitian yang menggambarkan pendapat terakhir peneliti. Kesimpulan ini diharapkan memiliki relevansi sekaligus menjawab focus penelitian yang telah dirumuskan sebelumnya.

\section{HASIL PENELITIAN DAN PEMBAHASAN}

\section{Deskripsi Pola Komunikasi Komunitas Anak Punk}

Pada penelitian ini penulis ingin melihat pola komunikasi antar anggota komunitas anak punk yang ada di Curup Provinsi Bengkulu. Dengan cara menganalisis tiga pola komunikasi menurut Effendy (1989: 32). Penulis melakukan wawancara terlebih dahulu dengan beberapa informan kunci dan informan pokok. Tidak hanya itu penulis juga melakukan observasi pada penelitian ini. Berdasarkan penelitian baik melalui wawancara dan observasi penulis melihat ketiga pola komunikasi menurut Effendy semua dipakai dalam komunikasi antar anggota komunitas anak punk di Kota Curup Kabupaten Rejang Lebong sebagaimana hasil wawancara dan observasi sebagai berikut:

\section{Pola Komunikasi Satu Arah}

Yaitu proses penyampaian pesan dari komunikator kepada komunikan baik menggunakan media maupun tanpa media, tanpa ada umpan balik dari komunikan, dalam hal ini komunikan bertindak sebagai pendengar saja. Berdasarkan hasil wawancara dan observasi berikut:

Berikut hasil wawancara penulis dengan saudara Pareng selaku yang dituakan oleh para anggota komunitas anak punk pada tanggal 27 September 2016:

"Komunikasi yang terjalin antara anggota kami cukup baik, dimana setiap saya menyampaikan pesan kepada mereka selalu mereka selalu mendengarkan dan mereka tidak pernah membantah setiap intruksi yang saya berikan"

Dalam penelitian ini penulis juga melakukan wawancara dengan informan pokok yaitu dengan saudara Agung pada tanggal 27 September 2016:

"Sejauh ini menurut pendapat saya komunikasi yang terjadi dalam komunitas kami sangat baik karena mereka saling menghargai dan menghormati antar sesama anggota komunitas" 
Untuk memperkuat wawancara penulis diatas, penulis juga mewawancarai saudara Funky pada tanggal 27 September 2016:

"Ya, komunikasi yang berjalan dalam komunitas kami ini berjalan dengan baik"

Disampaikan juga melalui wawancara penulis dengan saudara Rico pada tanggal 27 September 2016:

'Jadi, kalau menurut pendapat saya komunikasi yang terjadi dalam komunitas kami ini cukup baik."

Berikut wawancara penulis dengan saudara Pareng selaku informan kunci dalam penelitian ini pada tanggal 29 September 2016:

"Proses komunikasi dalam
komunitas kami ini tidak
membutuhkan waktu yang panjang,
mereka langsung menangkap apa
yang saya sampaikan. Jadi saya
tidak membutuhkan untuk
mengulang apa yang saya
sampaikan",

Dalam penelitian ini penulis juga melakukan wawancara dengan informan pokok yaitu saudara Agung pada tanggal 29 September 2016 dengan hasil sebagai berikut:

"Kami berkomunikasi tidak membutuhkan waktu yang lama, karena setiap memberikan informasi kami tidak panjang lebar kami langsung pada inti apa yang akan disampaikan."

Selanjutnya penulis juga mewawancarai saudara Funky pada tanggal 29 September 2016 dengan hasil sebagai berikut:

"Ya, proses komunikasi dalam komunitas ini baik dan tidak membutuhkan waktu yang lama"

Adapun yang disampaikan oleh saudara Rico pada tanggal 29 September 2016 dengan hasil sebagai berikut:

"Untuk menyampaikan informasi kami tidak membutuhkan waktu yang lama"

Berikut hasil wawancara penulis dengan saudara Pareng selaku informan kunci dalam penelitian ini pada tanggal 30 September 2016:

"Media yang sering kami lakukan untuk berkomunikasi yaitu handphone (HP)"

Dalam penellitian ini penulis juga melakukan wawancara dengan informan pokok. Berikut yang disampaikan oleh saudara Agung pada tanggal 30 September 2016 dengan hasil sebagai berikut:

"Kami di dalam berkomunikasi kesesama anggota biasanya menggunakan media elektronik seperti handphone $(H P)$ ",

Seperti halnya juga disampaikan oleh saudara Funky dalam wawancara dengan penulis pada tanggal 30 September 2016 dengan hasil sebagai berikut:

"Ya, sejauh ini kami biasanya berkomunikasi dengan sesama anggota komunitas hanya melakukan dengan handphone (HP) atau media sosial lainnya"

Disampaikan juga melalui wawancara penulis dengan saudara Rico pada tanggal 30 September 2016 dengan hasil sebagai berikut:

"Untuk berkomunikasi terkadang kami menggunakan media sosial seperti facebook, Instagram,biasanya kami mengakses melalui handphone (HP)"

Berdasarkan hasil wawancara, observasi penulis dalam pola komunikasi satu arah di atas, dapat dipahami Komunikasi yang berlangsung antara komunitas anak punk yang ada di Curup Provinsi Bengkulu ini berjalan dengan baik dan mereka mendengarkan apa yang diarahkan oleh saudara Pareng selaku yang dituakan dalam komunitas ini. Sedangkan media yang mereka gunakan untuk berkomunikasi yaitu media sosial seperti facebook, instagram dan media sosial lainya, yang diakses melalui media elektronik seperti handphone (HP).

Dari hasil observasi diatas, dapat disimpulkan bahwa komunikasi yang terjadi antar komunitas cukup baik karena 
saat melakukan komunikasi mereka saling menghargai dan menghormati antar anggota. Mereka lebih sering berkomunikasi dengan menggunakan media Handphone sehingga membuat mereka untuk mengikuti perkembangan zaman.

\section{Pola Komunikasi Dua Arah}

Seperti yang telah dijelaskan dalam pola komunikasi dua arah atau timbal balik (two way traffic communication) yaitu komunikator dan komunikan menjadi saling tukar fungsi dalam menjalani fungsi mereka, komunikator pada tahap pertama menjadi komunikan dan pada tahap berikutnya saling bergantian fungsi. Namun pada hakekatnya yang memulai percakapan adalah komunikator, komunikator mempunyai tujuan tertentu melalui proses komunikasi tersebut, yang prosesnya dijelaskan secara mendetil dan diharapkan mendapat umpan balik yang terjadi secara langsung. Berdasarkan penelitian baik melalui wawancara dan observasi penulis melihat ketiga pola komunikasi menurut Effendy semua dipakai dalam komunikasi antar anggota komunitas anak punk di Kota Curup Kabupaten Rejang Lebong sebagaimana hasil wawancara dan observasi sebagai berikut:

Berikut wawancara penulis dengan saudara Pareng selaku informan kunci dalam penelitian ini pada tanggal 06 Oktober 2016:

"Biasanya saya menyampaikan
pesan kepada anggota komunitas
yaitu dengan cara mengumpulkan
anggota komunitas ini kesuatu
tempat atau basecamp (balai)"

Dalam penelitian ini penulis juga melakukan wawancara dengan informan pokok yaitu dengan saudara Agung pada tanggal 06 Oktober 2016 dengan hasil sebagai berikut:

"Saya menyampaikan satu-persatu keanggota komunitas untuk berkumpul disuatu tempat”
Untuk memperkuat wawancara penulis di atas, penulis juga mewawancarai saudara Funky pada tanggal 06 Oktober 2016 dengan hasil sebagai berikut:

"Untuk meyampaikan pesan kepada anggota komunitas biasanya kami berkumpul di basecamp (balai) setelah ngolek"

Disampaikan juga melalui wawancara penulis dengan saudara Rico pada tanggal 06 Oktober 2016 dengan hasil sebagai berikut:

"Ya, sejauh ini tempat kami menyampaikan pesan dan bertukar pikiran hanya di basecamp (balai)"

Berikut hasil wawancara penulis dengan saudara Pareng selaku informan kunci dalam penelitian ini pada tanggal 08 Oktober 2016:

"Tujuan saya mengumpulkan anggota biasanya untuk melakukan suatu kegiatan seperti bergotongroyong dalam sebuah kebersihan serta menonton konser dan lainlain."

Dalam penelitian ini penulis juga melakukan wawancara dengan informan pokok yaitu dengan saudara Agung pada tanggal 08 Oktober 2016 dengan hasil sebagai berikut:

"Untuk menyampaikan suatu kegiatan yang positif seperti membantu masyarakat di daerah Curup seperti melacak (bongkar barang)"

Untuk memperkuat wawancara penulis diatas, penulis juga mewawancarai saudara Funky pada tanggal 08 Oktober 2016 dengan hasil sebagai berikut:

"Mengingatkan sesama anggota kalo ada masyarakat meminta tolong untuk menjaga cafe selagi diperlukan"

Disampaikan juga melalui wawancara penulis dengan saudara Rico pada tanggal 08 Oktober 2016 dengan hasil sebagai berikut:

"Biasanya tujuan kami berdiskusi untuk menyampaikan apa ada keluh kesan dalam anggota komunitas 
supaya kedepannya bisa lebih meningkatkan solidaritas sesama anggota komunitas punk"

Berikut hasil wawancara penulis dengan saudara Pareng selaku informan kunci dalam penelitian ini pada tanggal 09 Oktober 2016:

"Mendengarkan dan menerima dengan santai karena biasanya menjadi masukan dan ide untuk kemajuan komunitas ini"

Dalam penelitian ini penulis juga melakukan wawancara dengan informan pokok yaitu dengan saudara Agung pada tanggal 09 Oktober 2016 dengan hasil sebagai berikut:

"Ya, sebagian dari anggota bisa menerima dan sebagian anggota lainnya tidak bisa menerima"

Untuk memperkuat wawancara penulis di atas, penulis juga mewawancarai saudara Funky pada tanggal 09 Oktober 2016 dengan hasil sebagai berikut:

"Selagi pesan yang disampaikan itu bersifat membangun dan bermanfaat untuk komunitas, kami menerimanya"

Disampaikan juga melalui wawancara penulis dengan saudara Rico pada tanggal 09 Oktober 2016 dengan hasil sebagai berikut:

"Terkadang saya berdebat karena apa yang disampaikan tidak sesuai dengan apa yang saya pikirkan"

Berdasarkan wawancara, penulis dalam pola komunikasi dua arah di atas dapat dipahami yaitu pada dasarnya komunitas anak punk ini seperti sama halnya dengan komunitas-komunitas lainnya mereka mempunyai tujuan dan sering melakukan kegiatan-kegiatan seperti bergotong royong atau menjaga Cafe jika diperlukan oleh pemiliknya dan mereka ikut andil dalam kegiatan tersebut. Mereka juga saling mendengarkan dan kompak apabila ada salah satu dari mereka meminta untuk berkumpul, mendengarkan, dan menerima masukan dari anggota untuk kemajuan komunitas punk itu sendiri.

\section{Pola Komunikasi Multi Arah}

Yaitu Proses komunikasi terjadi dalam satu kelompok yang lebih banyak dimana Komunikator dan Komunikan akan saling bertukar fungsi secara dialogis. Berdasarkan penelitian baik melalui wawancara dan observasi penulis melihat ketiga pola komunikasi menurut Effendy semua dipakai dalam komunikasi antar anggota komunitas anak punk di Kota Curup Kabupaten Rejang Lebong sebagaimana hasil wawancara dan observasi sebagai berikut:

Berikut hasil wawancara penulis dengan saudara Pareng selaku informan kunci dalam penelitian ini pada tanggal 11 Oktober 2016:

"Saya memasuki komunitas anak punk ini karena saya ingin melakukan kebebasan dalam arti kebebasan yang positif, karena dalam keluarga saya terlalu banyak aturan-aturan yang tidak saya inginkan"

Dalam penelitian ini penulis juga melakukan wawancara dengan informan pokok yaitu dengan saurada Agung pada tanggal 11 Oktober 2016 dengan hasil sebagai berikut:

"Saya memasuki komunitas ini adalah karena kedua orang tua saya sudah meninggal dan keluarga besar saya tidak ada yang mau mengurus dan memperhatikan saya"

Untuk memperkuat wawancara penulis di atas, penulis juga mewawancarai saudara Funky pada tanggal 11 Oktober 2016 dengan hasil sebagai berikut:

"Yang mendasari saya bergabung dalam komunitas ini yaitu dengan keinginan saya sendiri"

Disampaikan juga melalui wawancara penulis dengan saudara Rico pada tanggal 11 Oktober 2016 dengan hasil sebagai berikut:

"Karena latar belakang keluarga saya yang keterbatasaan ekonomi, itulah yang mendasari saya bergabung menjadi anggota komunitas anak punk" 
Berikut hasil wawancara penulis dengan saudara Pareng selaku informan kunci dalam penelitian ini pada tanggal 13 Oktober 2016 :

"Ya, kami sering bertukar pikiran satu sama lainnya bukan hanya ketika kami sedang berkumpul saja, melainkan sewaktu kami juga tidak sengaja bertemu di jalan"

Dalam penelitian ini penulis juga melakukan wawancara dengan informan pokok yaitu dengan saudara Agung pada tanggal 13 Oktober 2016 dengan hasil sebagai berikut :

"Ya, sering saling memberi masukan

kepada sesama anggota komunitas anak punk untuk memajukan komunitas"

Untuk memperkuat wawancara penulis diatas, penulis juga mewawancarai saudara Funky pada tanggal 13 Oktober 2016 dengan hasil sebagai berikut:

"Kalau sedang berkumpul ya kami bertukar pikiran satu sama lain. Tentunya dalam hal untuk memajukan komunitas",

Disampaikan juga melalui wawancara penulis dengan saudara Rico pada tanggal 13 Oktober 2016 dengan hasil sebagai berikut:

"Ya, kami selalu bertukar pikiran serta memberi tahu kepada anggota apakah ada informasi penting untuk disampaikan"

Berdasarkan wawancara, observasi penulis dalam pola komunikasi multi arah diatas dapat dipahami, pada dasarnya komunitas terbentuknya anak punk di Curup Provinsi Bengkulu ini. Karena didasari oleh beberapa faktor seperti, keterbatasan ekonomi, ingin mendapatkan kebebasan, kehilangan kedua orang tua serta ada juga karena keinginan sendiri maka terbentuk komunitas anak punk, tujuan yang mereka harapkan dari komunitas anak punk ini yaitu mendapakan kebebasan, kebersamaan serta solidaritas dalam persahabatan.

\section{PEMBAHASAN}

Pola Komunikasi Antar Anggota Komunitas Anak Punk Di Kota Curup Kabupaten Rejang Lebong

Hasil penelitian dan pembahasan yang penulis peroleh di lapangan tentang komunikasi antar anggota komunitas anak punk Curup Kabupaten Rejang Lebong dengan menggunakan 3 pola komunikasi. Komunikasi yang dilakukan komunitas anak punk ini sudah berjalan dengan baik karena tidak terdapat perselisahan diantara mereka. Akan tetapi, dalam kehidupannya di dalam komunitas umumnya mereka menggunakan bahasa rejang ketika berkumpul. Adapun pola komunikasi yang dilakukan oleh komunitas ini dapat dilihat dari beberapa pola komunikasi yaitu:

\section{Pola Komunikasi Satu Arah}

Berdasarkan hasil observasi dan wawancara pola komunikasi satu arah antara penulis dan anak punk, tanpa ada umpan balik dari penulis dalam hal ini anggota komunitas punk bertindak sebagai pendengar saja atau komunikasi yang mengisyaratkan penyampaian pesan searah kepada seseorang dalam bentuk instruksi melalui media Handphone (HP). Dimana pola komunikasi yang dilakukan dalam komunitas ini berjalan dengan baik, dimana pada saat penulis menyampaikan informasi atau pesan kepada anggota komunitas anak punk, anggota komunitas anak punk selalu menerima dan melaksanakan tanpa ada umpan balik. Baik penyampaian pesan secara langsung maupun menggunakan media. Dan proses komunikasi dalam komunitas ini tidak membutukan waktu yang lama, mereka mampu menerima apa yang dikatakan oleh penulis. Sedangkan media yang mereka gunakan untuk berkomunikasi yaitu media social seperti facebook, instagram dan media sosial lainya, yang diakses melalui media elektronik seperti handphone (HP). Misalnya, informan kunci memberi instruksi untuk kumpul di Balai, komunitas langsung mengikuti untuk berkumpul di Balai. Berdasarkan wawancara yang dilakukan penulis, pola 
komunikasi satu arah digambarkan sebagaimana berikut ini :

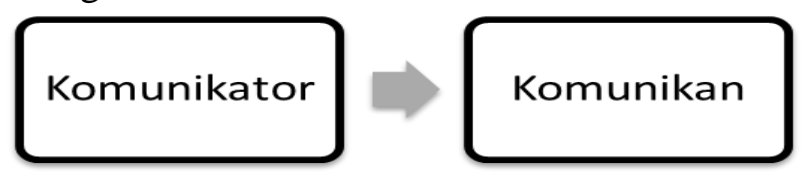

Gambar 1 Pola Komunikasi Satu Arah

\section{Pola Komunikasi dua arah atau timbal balik (Two way traffic communication)}

Berdasarkan hasil observasi dan wawancara pola komunikasi dua arah ini lebih memperjelas pola komunikasi satu arah dimana sebab-akibat yang arahnya bergantian karena adanya umpan balik (feed back) apakah pesan itu dapat dimengerti dan diterima. Penulis dan anggota komunitas anak punk menjadi saling tukar fungsi dalam menjalani fungsi mereka, penulis pada tahap pertama menjadi anggota komunitas anak punk dan pada tahap berikutnya saling bergantian fungsi. Namun pada hakekatnya yang memulai percakapan adalah penulis, penulis mempunyai tujuan tertentu melalui proses komunikasi tersebut.

Pada dasarnya setiap komunitas itu terdiri dari beberapa anggota agar komunitas itu berjalan dengan baik dan mereka mempunyai tujuan. Sama seperti halnya pada komunitas anak punk di Curup Kabupetan Rejang Lebong yang memiliki anggota 30 orang, diantaranya 5 perempuan dan 25 laki-laki. Dimana setiap anggota memiliki karakter yang berbedabeda. Akan tetapi dalam komunitas ini mereka mempunyai orang yang dianggap mengetahui komunitas. Sehingga membantu mereka untuk menyampaikan pesan, agar mereka tidak melakukan kericuhan ketika mendapatkan informasi yang akan disampaikan. Akan tetapi mereka juga berhak untuk menyampaikan pendapat mereka masing-masing dan menerima masukan atau saran dari anggota mereka.

Proses komunikasi yang mereka lakukan tidak membutuhkan waktu yang lama, biasanya mereka berkumpul atau berdiskusi untuk membahas sesuatu, untuk melakukan kegiatan-kegiatan seperti bergotong royong atau menjaga cafe jika diperlukan oleh pemiliknya dan mereka ikut andil dalam kegiatan tersebut. Mereka juga saling mendengarkan dan kompak apabila ada salah satu dari mereka meminta untuk berkumpul, mendengarkan dan menerima masukan dari anggota untuk kemajuan komunitas punk itu sendiri. Berdasarkan wawancara yang dilakukan penulis, pola komunikasi dua arah digambarkan sebagaimana berikut ini:

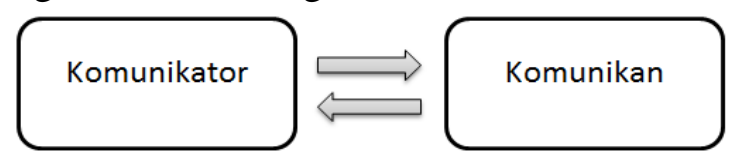

Gambar 2 Pola Komunikasi Dua Arah

\section{Pola Komunikasi Multi Arah}

Berdasarkan hasil observasi dan wawancara pola komunikasi multi arah ini, yaitu proses komunikasi terjadi dalam satu kelompok yang lebih banyak dimana penulis dan anggota komunitas anak punk akan saling bertukar pikiran secara dialogis. Walaupun mereka berasal dari latar belakang yang berbeda-beda mereka tetap menjaga hubungan baik dengan sesama anggota. Tujuan mereka sama yaitu mencapai tujuan yang lebih baik, untuk mewujudkan itu semua mereka saling bertukar pikiran atau berdiskusi dan menerima saran antar sesama komunitasnya melalui musyawarah yang dilakukan setiap bulannya mereka berkumpul untuk mengeluarkan ide-ide yang disampaikan, ditampung sehingga yang disimpulkan mendapat kesepakatan untuk melakukan kegiatan seperti Festival Band (Pentas Seni). Sehingga hal tersebut, bisa berguna untuk kemajuan anggota komunitas anak punk dan mempererat hubungan antar anggota komunitas. Berdasarkan wawancara yang dilakukan penulis, pola komunikasi multi arah digambarkan sebagaimana berikut ini : 


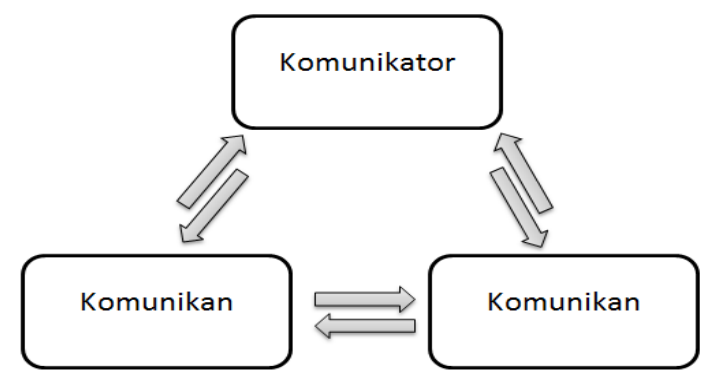

Gambar 3 Pola Komunikasi Multi Arah

\section{PENUTUP}

\section{Kesimpulan}

Berdasarkan hasil penelitian pada bab sebelumnya telah menjelaskan bagaimana pola komunikasi antar anggota komunitas anak punk di Kota Curup Kabupaten Rejang Lebong. sehingga dapat ditarik kesimpulan sebagai berikut:

1. Pola komunikasi satu arah antara penulis dan anak punk cukup baik. Dalam hal ini anggota komunitas punk bertindak sebagai pendengar saja atau komunikasi yang mengisyaratkan penyampaian pesan searah kepada seseorang dalam bentuk intruksi melalui media Handphone (HP). Dan disini, komunitas saling menghargai dan menghormati atas instruksi yang diberikan.

2. Pola komunikasi dua arah ini lebih memperjelas pola komunikasi satu arah dimana sebab-akibat yang arahnya bergantian karena adanya umpan balik (Feed back) apakah pesan itu dapat dimengerti dan diterima. Pola komunikasi dua arah atau timbal balik (Two way traffic communication) yang disampaikan Key Informan dalam komunitas mendapat respon yang baik dari anggota untuk melakukan kegiatankegiatan yang berdampak positif seperti bergotong royong, menjaga café jika diperlukan oleh pemiliknya dan lainlain.

3. Pola komunikasi multi arah yang terjadi pada komunitas ini berjalan dengan baik, karena disini mereka saling bertukar pikiran atau berdiskusi dan menerima saran antar sesama komunitasnya melalui musyawarah yang dilakukan setiap bulannya mereka berkumpul untuk mengeluarkan ide-ide yang disampaikan, ditampung sehingga yang disimpulkan mendapat kesepakatan untuk melakukan kegiatan seperti Festival Band (Pentas Seni). Sehingga hal tersebut, bisa berguna untuk kemajuan anggota komunitas anak punk dan mempererat hubungan antar anggota komunitas.

\section{Saran}

Berdasarkan hasil dari penelitian yang telah dilakukan penulis dengan judul Pola Komunikasi Antar Anggota Komunitas Anak Punk di Kota Curup Kabupaten Rejang Lebong maka penulis memberikan saran sebagai berikut:

1. Komunitas anak Punk

Para Punk diharapkan untuk memikirkan kembali gaya hidup sebagai seorang anak Punk dan mulai merencanakan masa depan, serta mewujudkan tujuan-tujuan hidupnya dengan bakat dan potensi yang mereka miliki.

2. Masyarakat

Diharapkan memiliki sikap yang lebih bijaksana dalam memandang keberadaan komunitas Punk, mencoba memahami bagaimana budaya Punk dan kehidupan seorang Punk yang sebenarnya, serta berpikir positif dengan tidak menciptakan stigmastigma negatif terhadap komunitas Punk.

3. Pemerintah setempat dan kepolisian Melakukan pembinaan khusus untuk program-program latihan kerja agar anak Punk mampu menjalani kehidupannya dengan baik. Misalnya memberikan wadah atau tempat aspirasi bermusik sebagai ajang berprestasi bagi aliran musik Punk, kemudian memberikan fasilitas untuk latihan band dan penggunaan sound systemnya. 
DAFTAR PUSTAKA

Craig O'Hara. (1999). The philosopy of Funk: more Than Noise. San Fransisco: A K Press.

Effendy, Onong Uchjana. (2003). Ilmu Komunikasi Teori dan Praktek Catatan Kesembilan belas. Bandung: PT Remaja Rosdakarya.
Herdiansyah, Haris. (2010). Metodologi Penelitian Kualitatif. Jakarta: Salemba Humanika.

Santorck. (2003). Perkembangan remaja. Jakarta :Erlangga

Sugiyono. (2010). Metode Penelitian kualitatif dan Kuantitatif $R \& D$. Bandung: Penerbit Alfabeta. 